\title{
Parental Perspective in the Finnish Early Childhood Education Context
}

\author{
Purola, Karoliina
}

Routledge

2021-10

Purola , K , Harju-Luukkainen , H \& Kangas , J 2021, Parental Perspective in the Finnish Early Childhood Education Context . in S Garvis , S Phillipson, H Harju-Luukkainen \& A R

Sadownik (eds), Parental Engagement and Early Childhood Education Around the World . Envolving Families, Routledge , London, New York, pp. 90-98 . https://doi.org/10.4324/9780367823917-8

http://hdl.handle.net/10138/337661

https://doi.org/10.4324/9780367823917-8

unspecified

draft

Downloaded from Helda, University of Helsinki institutional repository.

This is an electronic reprint of the original article.

This reprint may differ from the original in pagination and typographic detail.

Please cite the original version. 


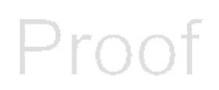

\title{
8
}

\section{PARENTAL PERSPECTIVE IN \\ FINNISH EARLY CHILDHOOD EDUCATION CONTEXT}

\author{
Karoliina Purola, Heidi Harju-Luukkainen \\ and Jonna Kangas
}

\section{Introduction}

There are four steering documents that guide the Finnish Early Childhood Education and Care (ECEC) sector: (1) Act on Early Childhood Education and Care (540/2018); (2) FNAE - National Core Curriculum for Early Childhood Education and Care (Finnish National Agency for Education, 2018); (3) FNBE - National Core Curriculum for Pre-Primary Education (Finnish National Board of Education, 2016), and (4) Guidelines and recommendations for evaluation of the quality of early childhood education and care (Finnish Education Evaluation Centre, 2018). The first two documents guide the work for children under the age of six, and the third applies to work with children during the preschool year. Preschools in Finland are under the Basic Education Act (628/1998), but are mostly managed by ECEC centres. The fourth guide sets the indicators to evaluate the ECEC provision from different perspectives. These three first documents were prepared in collaboration with specialist educators from the field and included ECEC specialists, researchers, trade union representatives, and administrators. The responsibility for ECEC on the national level lies with the Ministry of Education and Culture; on the local level it is the municipalities that are responsible for arranging the different ECEC services and ensuring their quality and supervision. The Finnish ECEC is based on an integrated approach supporting children's well-being through care, education, and teaching, the so-called educare model where learning through play has centre stage (see Kangas, Ojala, \& Venninen, 2015).

The cooperation (also called the partnership, parental involvement or parental collaboration) with the parents is highlighted in the Finnish ECEC steering documents. An entire chapter in the national core curriculum is devoted to discussing parental participation and its implementation. According to the National Core Curriculum for ECEC (Finnish National Agency for Education FNAE), the aim 
for the partnership cooperation is in meeting the needs of the child to ensure their growth, development, and learning. The previous Finnish National Curriculum Guidelines for Early Childhood Education and Care (STAKES, 2005) emphasised parent-teacher cooperation as a partnership. Within this document, the partnership between ECEC teachers and parents is defined by such terms as, "trust, respect, and equality ... and parental knowledge" (Alasuutari, 2010, p. 150). It is claimed that the partnership aspect of cooperation was changing the role of parents to that of clients. This claim raised concerns over challenges in developing such parentteacher cooperation and the processes associated with the cooperation (Vlasov \& Hujala, 2016).

The new Core Curriculum (FNAE, 2018) discusses cooperation and parental participation from a new perspective. Today the teachers are obligated to offer parents an opportunity to participate in designing and evaluating the educational programme regularly, as well as joining the process for creating, implementing, and assessing their child's personal curriculum for early education. They can do this through a document that is reflected on and revised by teachers and parents in a joint meaning-making process (Uusimäki, Yngvesson, Garvis, \& Harju-Luukkainen, 2019; FNAE, 2018).

The Finnish Education Evaluation Centre (FEEC) presents the new quality indicators for ECEC to guide municipalities and ECEC provisions (2018). The FEEC has listed several indicators for parental participation. These indicators measure how the municipalities and teachers guide and inform parents about the forms of education and the goals and objectives of the pedagogy. The guidance from municipalities is important for families to be able to choose the right ECEC service for their child. For example, they would have to decide if they want full day, half-day or up to 20 hours per week at ECEC, family day care; parents have the right to choose the amount, location and level of education. In the FEEC's indicators, teachers and supporting teachers' ability to plan and execute the transition phase from home to school is evaluated where children's experiences of safety and belonging are highly valued. Finally, quality indicators point out that parents have a right to participate in designing, planning, implementing and assessing the daily education with teachers. Therefore, we may conclude that the recent steering documents in Finland oblige teachers and ECEC provisions to create a framework for parental participation and highlight the mutual planning and assessment of a child's educational plan.

In this chapter, we take a closer look at research connected to parental participation, and how teacher training programmes take this into consideration in the course contents. After that, we turn our focus towards how this partnership is conducted in practice and finally take a critical perspective on future developmental objectives on the field of ECEC and parental collaboration.

\section{Research connected to parental participation}

Early childhood education between ages 1 and 5 is voluntary in Finland. Parents can choose if they would like to put their child into an early childhood education facility or care for their child at home. Early childhood services are offered 
in a wide range of settings. Parents may choose an ECEC service for their child among multiple options: full day, half-day, or needed days per week. Parents can also choose between an ECEC centre and family day care, and further between public and private organisers. In practice, the municipality offices for ECEC offer their support for parents to make these decisions. After starting the ECEC, the responsibility of cooperation moves from the administrative level to the ECEC centre's teachers and director where the demand for collaborative participation requires expert collaboration skills as well as understanding and respect from the teachers (see closer Uusimäki et al., 2019). Not all parents have equal opportunities to participate. According to Lammi-Taskula and Siippainen (2018), those parents who work night shift had fewer opportunities to participate in ECEC parents' conferences, special events, and conversations in comparison to those parents who worked traditional hours in Finland.

Parental participation in ECEC has been under the governance of the Ministry of Social and Health Affairs until the year 2012. After that, it was transformed under the governance of Ministry of Education and Culture. This has had its natural effects on both the research conducted and the terms used in the literature. Onnismaa (2010) studied the Finnish steering documents from 1967 to 1999. In those previous documents, according to Onnismaa (2010), parents were considered as weak participants who needed help and guidance, whereas the children were seen as capable individuals. The assumption is that weak parents may reflect negatively on the cooperation between teachers and parents. Since the governance of ECEC has moved under the Ministry of Education and Culture, the view on parental partnership has changed. Further, parents have become more involved in the process of creating steering documents.

Collaboration between ECEC and parents can be viewed from different perspectives. According to Alasuutari (2010), the challenge in this collaboration is to agree on the interpretation of participation for both teachers and parents. Mahmood (2013) also studied collaboration and noted that teachers can find this collaboration challenging if the roles and responsibilities of the cooperation have not been clearly stated in steering documents and practice. The teachers' professional skills and level of education have been found to affect the formation of a successful collaboration with parents; thus, teachers need expert skills to develop collaboration skill regarding parental cooperation (Chan \& Ritchie, 2016; Mahmood, 2013; Uusimäki et al., 2019). Hakyemez-Paul, Pihlaja, and Silvennoinen (2018) conducted a study with a sample of 287 Finnish ECEC teachers. According to the results, the professionals have in general a positive attitude towards parental involvement. Further, the participants stated that difficulties in parental involvement are often caused by poor parental motivation, and a lack of time on the part of both teachers and parents. A deeper analysis revealed that these positive attitudes were somewhat superficial, and ECEC teachers wanted to restrict education to institutions, and regard parents as passive. These attitudes teachers have can be viewed from many perspectives. In their study Venninen and Purola (2013) identified three different ways to characterise teachers' attitudes concerning parental participation in ECEC; 
these were (1) the professional, (2) the customer, and (3) the partnership perspective. In the professional perspective, the ECEC professional takes an expert role in discussions with parents. From the customer perspective, parent satisfaction is the driving force. The challenge for ECEC teachers from the customer perspective might be that the expertise, responsibility and experience of the child lie with the parents. The partnership perspective includes the two previous perspectives. The teacher who acquires the partnership standpoint seems to have best opportunities to cooperate successfully with parents.

An International Parent-Professional Partnership research study conducted by Hujala, Turja, Gaspar, Veisson, and Waniganayake (2009) focused on the contemporary challenges of parent-teacher partnerships in early childhood education from a cross-cultural perspective. The purpose of the research was to examine parentteacher partnerships in ECEC services in five countries: Estonia, Finland, Lithuania, Norway, and Portugal. The survey questionnaire focused on teachers' views of parents' involvement in ECEC facilities. According to the results, there were differences in teachers' approaches to parent-teacher partnerships from one society to another as well as within each country. Parents also differed in their capacity to develop and maintain partnerships with teachers. There were differences in the professional status of the teachers in each country, which were connected to the parents' role in the parent-teacher partnerships in ECEC services. According to Vlasov and Hujala (2017), ECEC services maintain a central role in supporting families with young children. How this partnership between families and service providers is conducted and understood is dependent on the political, societal and cultural changes in a national context. Therefore, the teachers' interpretation of the collaboration is not the only determinant; there may be many other societal factors that influence the success of this collaboration.

\section{Cooperation with parents as a subject in Finnish teacher training programmes}

The cooperation between parents and teachers depends on teachers' professional skills and quality (Uusimäki et al., 2019; Alasuutari, 2010; Mahmood, 2013). Parental participation follows the professional practices and knowledge of educational goals. In teacher education, students are trained in curriculum work, interaction with children, and the development of educational practices. Above that, Finnish teacher education aims to promote the critical thinking and reflection skills of future teachers so that they can not only follow educational policies and practices but also act as active agents to change them (Niemi, Toom, \& Kallioniemi, 2016). All these depend on the quality of teacher education (Mahmood, 2013). Finnish teacher education focuses on the pedagogical thinking processes and capabilities to design, implement, document, evaluate and critically reflect on the processes of teaching and learning. In Finland teacher training aims to give teachers toolboxes to cope with an unknown future (Seikkula-Leino, Satuvuori, Ruskovaara, \& Hannula, 2015). Parental participation has been a topic among other cooperative and 
multiprofessional practices in teacher training programmes. This approach views teaching as a dynamic and dialogic profession with much networking and joint work. Researchers around the world have highlighted a need to move from traditional teacher-dominated practices towards dialogic and dynamic spaces of cooperation that include engagement with parents (see Chan \& Ritchie, 2016; Lastikka, 2019).

Finnish ECEC teachers are trained in universities and are qualified with a bachelor's degree in Education. Their training programme focuses on the learning and development of children, and the curriculum and subjects of teaching within the educational context. Cooperation with parents is covered in courses in which students familiarise themselves with the plan for a child's development and learning. The diversity of different families is also addressed as part of the teacher training programme. Some universities collaborate with parental organisations and organise specialised lectures on how to put this parental partnership into practice.

In order to gain a better understanding of the contents in teacher education connected to parental participation, we conducted a brief content analysis of eight universities' curriculums in Finland that offer Baccalaureate programmes in early childhood education. We analysed the curriculums to identify 'key features' of each document that we wanted to examine (see Williams, 2007). The searches were done on concepts around parental collaboration, partnership or other keywords that were connected to this area of interest (see Leedy \& Ormrod, 2001). The searches were done in both concepts of studies and objectives of studies. This curriculum analysis provides an overview comparison among the different universities' concepts and learning objectives in the education programmes in the area of parental collaboration (see Table 8.1).

According to the results of this content analysis, the university curriculums have quite a few mentions of the concepts of 'parents' and 'family', but more emphasis has put on the concept of 'professional co-operation'. In fact, 'parental participation' is hardly mentioned in any of the curricula. The curricula have more mentions of the concepts itself than learning objectives in studies, and there is some variation among the universities.

\section{Partnership in practice}

Cooperation has multiple functions and can take on different forms during the child's ECEC according to the steering documents (FNAE, 2018; FNBE, 2016). The initiation of cooperation is the role of the ECEC teachers, and requires expert collaboration skills in meeting families with understanding and respect (see for instance Uusimäki et al., 2019; Alasuutari, 2010; Mahmood, 2013). The child's everyday learning and development experiences that are shared with parents, or creating a trusting environment between the parents and teachers are important. These interactions are especially important in challenging situations, where for example there is a concern about the child's well-being. The observations parents and the teachers make and share with each other forms the basis for a perception 
of the child's overall well-being and positive development. These occasions where these matters are discussed thoroughly are held two or three times a year during an ECEC education plan conversation. In these conversations, it is important to have an open and positive dialogue between parents and teachers to support the child's learning and development, particularly in meetings when a translator may be needed so that both parties can understand one another. This is important when special support is identified for a child, and the parents must meet with the child support team. Educational and support plans are described in more detail within the national core curriculum. Cooperation is also crucial during transitional phases, whether the child begins the ECEC, he/she enters the next level in ECEC, or is transferred to year one of primary school. The municipal ECEC steering documents guide these transitional phases rather closely. For instance, in

TABLE 8.1 Parental collaboration as objectives and concept of studies in teacher education programmes

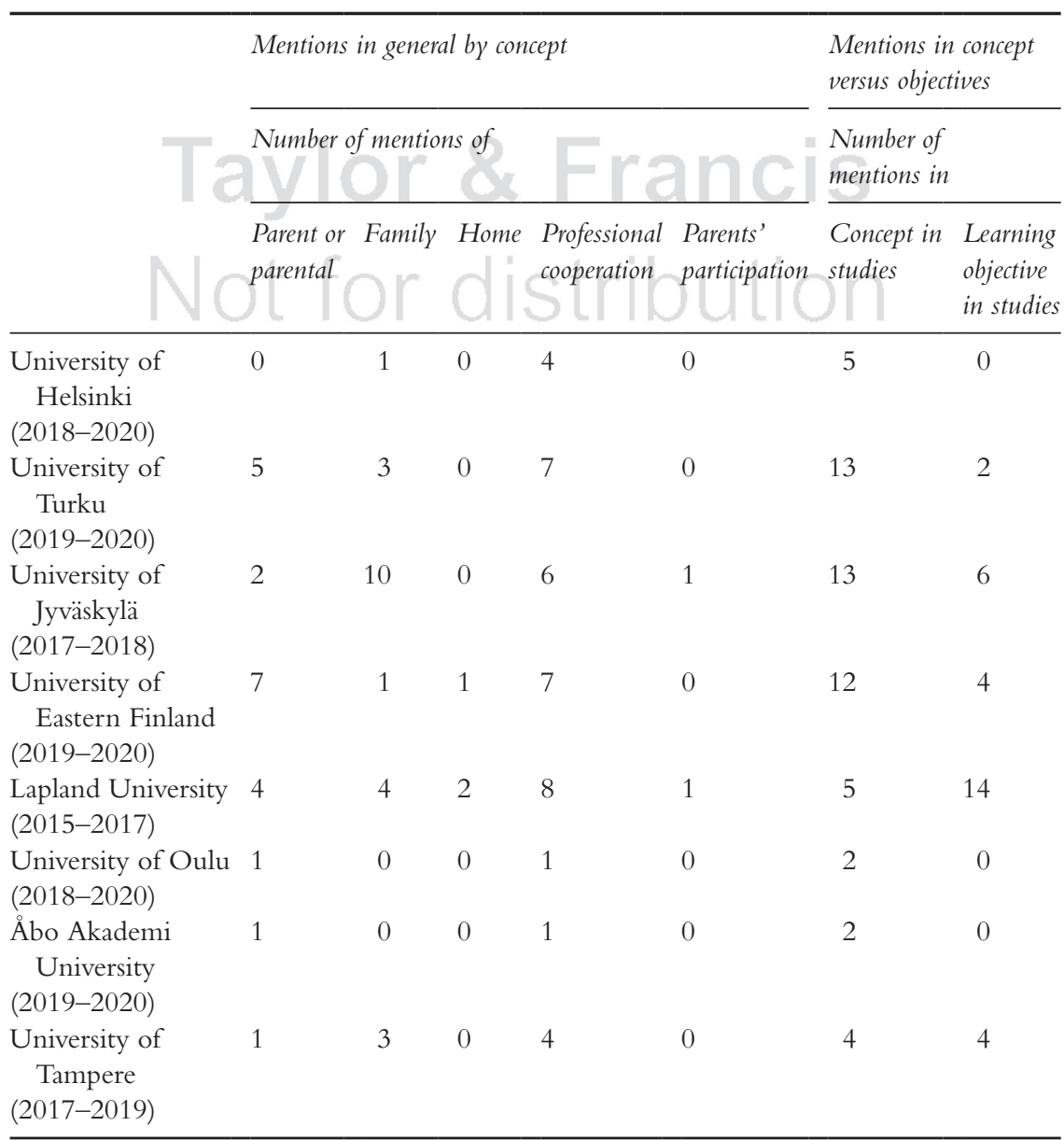


Kirkkonummi (municipality in Finland) all families are offered a first discussion at home. Parents are also invited to the day-care centre with the child for a week or two so that the child becomes familiar with the teachers, other children and the premises. This gives the parents an opportunity to take part and support the child's participation and share and discover what she/he likes and wants.

Many parents in ECEC are involved in parental association voluntary work. Parent associations in ECEC provisions are held by voluntary parents in preschools. The associations organise different programmes, collect funds at different events and with the help of these are able to finance trips or provide other needed materials. Through these local associations, parents have a way to influence the programme more on a practical level. Often these local associations are organised under the main national parents' associations called Suomen Vanhempainliitto and Förbundet Hem och Skola i Finland r.f., for the Swedish and Finnish language preschools and schools. These two parent organisations collaborate as a central association organising local parent associations in schools and preschools. The central associations provide a variety of projects and information in different forms for both parents and teachers. They also work with policymakers across the country. The goal of this work is to strengthen a positive dialogue between parents and early childhood and school environment as well as bring forth parents' voices. The associations have a functional status in the society, and they employ several full-time specialists. Further, both of the associations are members in Nordic parental collaboration association called NOKO (Nordiska föräldraorganisationernas samarbete inom Nordisk Kommitté) and are also taking part in the meetings of European Parents' Association (EPA). The national associations collaborate with the teacher education departments and organise lectures where the parent and preschool or school collaboration is highlighted (more about the association work can be found from www.hemochskola.fi and www.vanhempainliitto.fi).

\section{Future developmental objects}

Though there is an understanding that parents have an important role in children's upbringing, there seems to be very little research on this area, especially in Finland. Even though the latest curriculum for ECEC in Finland (FNAE, 2018) highlights the collaboration with parents, this has not yet been transferred yet to the steering documents or contents of different teacher education programmes. This is a clear developmental object for the future since teachers need expert skills for this collaboration (Chan \& Ritchie, 2016; Mahmood, 2013; Uusimäki et al., 2019).

Following the Act on ECEC in Finland (540/2018) and the National Curriculum (FNAE, 2018), parents should be included in developing the ECEC curriculum, environment and practices together with the children and teachers. In practice, this would need a more developed digital solution, which is encouraged to be used and developed. For example, all necessary contact information as well as curricula, locations and developmental goals for municipal education can be found online. A challenge lies with keeping parents up to date on their children's everyday 
activities at the ECEC centre, and the delivery of children's learning processes and outcomes. These learning processes are difficult to document even for teachers, because of the nature of multidimensional learning and participation of children in ECEC in Finland (Rintakorpi \& Reunamo, 2017). Different tools for pedagogical documentation such as digital portfolios to enhance parental participation have been developed in Finland during the past decade; they have been partly funded by the government (Purola \& Smeds, 2018).

The FEEC (2018) has begun to gather information from municipalities on how well the ECEC quality indicators are met, and these results point to the need for further teacher training on parental participation. The results also indicate how parental participation and structures in day-care centres should be developed in different locations, as they are not all the same.

These findings indicate that the Finnish steering documents highlight parental participation in ECEC, and the teaching of parental participation in teacher education is important. The latest research on multicultural families in Finnish ECEC suggests that teachers need more training on how to cooperate with different kinds of parents and in difficult situations (Hakyemez-Paul et al., 2018; Lastikka, 2019). There is a very limited research into parents' view on parental participation in Finland, and more study is required before parental participation can be enhanced further in Finnish ECEC.

\section{References}

Act on Early Childhood Education and Care. (540/2018). Retrieved from www.finlex.fi/ fi/laki/alkup/2018/20180540

Alasuutari, M. (2010). Striving at partnership: Parent - practitioner relationships in Finnish early educators' talk. European Early Childhood Education Research Journal, 18(2), 149-161.

Basic Education Act. (628/1998). Retrieved from www.finlex.fi/en/laki/kaannokset/1998/ en19980628.pdf

Chan, A., \& Ritchie, J. (2016). Parents, participation, partnership: Problematising New Zealand early childhood education. Contemporary Issues in Early Childhood, 17(3), 289-303.

Finnish Education Evaluation Centre. (2018). Guidelines and recommendations for evaluating the quality of early childhood education and care (J. Vlasov, J. Salminen, L. Repo, K. Karila, S. Kinnunen, V. Mattila, T. Nukarinen, S. Parrila, \& H. Sulonen, Eds.). Retrieved August 12, 2019, from https://karvi.fi/app/uploads/2019/03/FINEEC_Guidelinesand-recommendations_web.pdf

Finnish National Agency for Education. (2018). The national core curriculum for early childhood education and care. Retrieved from https://www.julkari.fi/bitstream/ handle/10024/75535/267671cb-0ec0-4039-b97b-7ac6ce6b9c10.pdf?sequence=1

Finnish National Board of Education. (2016). National core curriculum for pre-primary education 2014. Helsinki: Author.

Hakyemez-Paul, S., Pihlaja, P., \& Silvennoinen, H. (2018). Parental involvement in Finnish day care - what do early childhood educators say? European Early Childhood Education Research Journal, 26(2), 258-273. doi:10.1080/1350293X.2018.1442042

Hujala, E., Turja, L., Gaspar, M. F., Veisson, M., \& Waniganayake, M. (2009). Perspectives of early childhood teachers on parent - teacher partnerships in five 
European countries. European Early Childhood Education Research Journal, 17(1), 57-76. doi:10.1080/13502930802689046

Kangas, J., Ojala, M., \& Venninen, T. (2015). Children's self-regulation in the context of participatory pedagogy in early childhood education. Early Education and Development, 26(5-6), 847-870.

Lammi-Taskula, J., \& Siippainen, A. (2018). Vanhempien vuorotyö, lasten hyvinvointi ja yhteistyö vanhempien kanssa varhaiskasvatuksessa [Parents' shift work, wellbeing of the children and cooperation with parents in early childhood education]. Yhteiskuntapolitiikka, 83(4), 422-426.

Lastikka, A. L. (2019). Culturally and linguistically diverse children's and families' experiences of participation and inclusion in the Finnish early childhood education and care. Helsinki: Unigrafia. Retrieved from http://urn.fi/URN:NBN:fi-fe2019102835162

Leedy, P., \& Ormrod, J. (2001). Practical research: Planning and design (7th ed.). Upper Saddle River, NJ: Merrill Prentice Hall; Thousand Oaks: Sage.

Mahmood, S. (2013). First-year preschool and kindergarten teachers: Challenges of working with parents. School Community Journal, 23(2), 55-85.

Niemi, H., Toom, A., \& Kallioniemi, A. (Eds.). (2016). Miracle of education: The principles and practices of teaching and learning in Finnish schools. Rotterdam: Springer.

Onnismaa, E. L. (2010). Lapsi, lapsuus ja perhe varhaiskasvatusasiakirjoissa 1967-1999 [Child, childhood and family in early childhood education documents]. Helsinki: Helsingin yliopisto.

Purola, K., \& Smeds, K. (2018). Huoltajien kokemukset ja osallisuus digitaalisten portfolioiden kehittämisessä ja kokeilemisessa [Parents' experiences and participation in development and experiment of digital portfolio]. In K. Smeds (Ed.), Diggaa mun digimatkaa - Digga min digiresa - digitaaliset portfoliot varhaiskasvatuksen pedagogisen toimintakulttuurin kehittämisessä. Report. Retrieved from https://indd.adobe.com/ view/9ce1fc00-a197-48e0-851f-c0d88ee6b402

Rintakorpi, K., \& Reunamo, J. (2017). Pedagogical documentation and its relation to everyday activities in early years. Early Child Development and Care, 187(11), 1611-1622.

Seikkula-Leino, J., Satuvuori, T., Ruskovaara, E., \& Hannula, H. (2015). How do Finnish teacher educators implement entrepreneurship education? Education + Training, 57(4), 392-404.

STAKES. (2005). Finnish national curriculum guidelines for early childhood education and care. Retrieved from e_vasu (julkari.fi)

Uusimäki, L., Yngvesson, T. E., Garvis, S., \& Harju-Luukkainen, H. (2019). Parental involvement in ECEC in Finland and in Sweden. In S. Garvis, H. HarjuLuukkainen, S. Sheridan, \& P. Williams (Eds.), Nordic families, children and early childhood education: Studies in childhood and youth (pp. 81-99). Cham: Palgrave Macmillan. doi:10.1007/978-3-030-16866-7_5

Venninen, T., \& Purola, K. (2013). Educators' view on parents' participation on three different identified levels. Journal of Early Childhood Education Research, 2(1), 48-62.

Vlasov, J., \& Hujala, E. (2016). Cross-cultural interpretations of changes in early childhood education in the USA, Russia, and Finland. International Journal of Early Years Education, 24(3), 309-324.

Vlasov, J., \& Hujala, E. (2017). Parent-teacher cooperation in early childhood education directors' views to changes in the USA, Russia, and Finland. European Early Childhood Education Research Journal, 25(5), 732-746.

Williams, C. (2007). Research methods. Journal of Business and Economic Research, 5(3), 65-71. 